
\title{
28 Research Suare \\ Factors Contributing to the High Prevalence of Multidrug- Resistant/Rifampicin-Resistant Tuberculosis: A Study From Russia
}

llia Bykov

Far Eastern State Medical University

Olga Dyachenko

Far Eastern State Medical University

Pavel Ratmanov

Far Eastern State Medical University

Qunhong Wu ( $D$ wuqunhong@163.com )

Harbin Medical University

\section{Research Article}

Keywords: multidrug-resistant/Rifampicin-resistant tuberculosis, risk factors, tuberculosis, disability, penitentiary facilities

Posted Date: December 21st, 2021

DOI: https://doi.org/10.21203/rs.3.rs-1130356/v1

License: (9) This work is licensed under a Creative Commons Attribution 4.0 International License. Read Full License 


\section{Abstract}

Background: Rapidly growing prevalence of multidrug-resistant/Rifampicin-resistant tuberculosis (MDR/RR-TB; resistance to Isoniazid and Rifampicin/Isolated resistance to Rifampicin) is putting in jeopardy the WHO End TB strategy. This study aimed to identify factors contributing to the high prevalence of MDR/RR-TB in Khabarovsk krai region of Russia.

Methods: A cross-sectional retrospective study was conducted. Clinical, demographic and drug susceptibility testing data on 1440 patients were analyzed. Factors associated with MDR/RR-TB were identified through logistic regression analysis, along with in-depth interviews with eight patients, five healthcare managers and five doctors.

Findings: 618 patients (42.9\%) were identified with MDR/RR-TB. Patients with a history of imprisonment were 16.53 times ( $95 \% \mathrm{Cl} 5.37$ to 50.88 ,) more likely to have MDR/RR-TB, whereas re-treatment patients were 2.82 times ( $95 \% \mathrm{Cl} 2.16$ to 3.66) more likely to have MDR/RR-TB. Other influencing factors included presence of disability (AOR is $2.32,95 \% \mathrm{Cl} 1.38$ to 3.89 ) and cavitary disease (AOR is $1.76,95 \% \mathrm{Cl} 1.37$ to 2.25). Poor knowledge, progressive tiredness of prolonged TB treatment and inability to hospitalize infectious patients without their consent were perceived by the interviewees as major influencing factors.

Conclusions: Incarceration and treatment history, regardless of outcome, were identified as major factors influencing MDR/RR-TB prevalence. It is essential for TB care system to eliminate legal loopholes, which deprive doctors of means to enforce quarantine procedures and epidemiological surveillance on infected patients, former and current inmates. In addition, increasing people's awareness of TB, early detection and appropriate treatment of patients with TB are needed for successfully combating MDR/RR-TB.

\section{Introduction}

The continuous increase of multidrug-resistant/Rifampicin-resistant tuberculosis (MDR/RR-TB; resistance to Isoniazid and Rifampicin/Isolated resistance to Rifampicin) throughout the globe is a major public health issue. Treatment of MDR/RR-TB is more toxic to the patient, less effective (the 2019 reported global treatment success rate is only $56 \%$ ) and carries much higher economic burden on the patients and the healthcare system, thus jeopardizing TB control efforts in developed and developing counties alike [13].

Russia carries one of the greatest burdens of MDR/RR-TB in the world. In 2019, MDR/RR-TB accounted for $35 \%$ of all new TB cases and $71 \%$ of all previously treated TB cases, with an MDR/RR-TB incidence of 27 per 100,000. Even so, the number of detected TB cases in Russia is continuously falling; the prevalence of MDR/RR-TB cases in Russia is the second highest in the world despite occupying only 23rd rank of total TB incidence [4-5].

Alarmed by the serious general epidemic TB situation and high MDR/RR-TB prevalence in particular, the government of the Russian Federation alongside the Russian Society of Physiologists have developed 
specific policies and guidelines corresponding with WHO TB strategy and guidelines in order to eradicate the existing issues [8]. Thus, joint TB control programs with international partners have been initiated, research funds have been extended, centralized electronic database of patients created, and new diagnostic techniques and policies implemented. However, progress is far from satisfactory, as despite the overall decrease in total TB incidence, the prevalence of MDR/RR-TB is continuing to rise $[4,6-7]$.

It is crucial to identify the underlying reasons for such high MDR/RR-TB prevalence so that more feasible and cost-effective approaches can be developed to control this trend. International reviews as well as some country-level studies have identified that risk factors for MDR/RR-TB vary depending on country, region, or locality. Among the most prevalent are poverty, overcrowding, HIV co-infection, diabetes, alcoholism, smoking, cavitary disease and even young age. Thus, in clinical practice, it is essential to assess general risk factors as well as ones specific to the region of residence of the patients [8-13].

This study was undertaken in Khabarovsk Krai, in the Far East of Russia, where the proportion of MDR-TB among newly diagnosed cases (38\%) was estimated to be the third highest in the country, significantly higher than the national average of $29.3 \%$ in 2018 [14]. Unfortunately, there is a notable gap in research into MDR/RR-TB rates between high and low prevalence regions of Russia. Despite some studies carried out in low-prevalence regions, factors influencing MDR/RR-TB in high-prevalence regions have rarely been investigated [15-17].

\section{Methods}

Data collection:

The study was conducted in the central "Tuberculosis Hospital" of Khabarovsk Krai. This institution collects and processes information about all patients with tuberculosis in Khabarovsk Krai and functions as a reference laboratory at the regional level. The Federal Register of TB patients (FRTP) was used in this study as a source of data, which is a subsystem of the digital Unified State Healthcare Information System (USHIS). Anonymous data on every patient that was diagnosed with TB in Khabarovsk Krai from January 2018 to December 2019 was collected. The surveillance covered all healthcare institutions in the region and strictly followed the guidelines developed by the WHO and the International Union against Tuberculosis and Lung Disease [19].

Diagnostic and including criteria:

An acid-fast bacilli sputum smear, culture (with both liquid and solid media) and real time PCR alongside with Drug Susceptibility Testing (DST) are routinely implemented as initial diagnostic tests in all patients with suspected TB in Khabarovsk Krai. In this study, a patient whose sample was positive for mycobacterium tuberculosis (MTB) in at least one of the 4 initial diagnostic tests was defined as having active pulmonary TB. Patients whose samples were negative for the MTB in all 4 initial diagnostic tests were defined as having non-active pulmonary TB and were thus excluded from the study. 
Various DST techniques were employed to detect MDR/RR-TB in patients. DST alongside the sputum culture tested MTB resistance to most first and second-line anti-TB drugs.

A liquid and solid media sputum culture tested MTB resistance to the following agents: Isoniazid, Rifampicin, Ethambutol, Streptomycin, Linezolid, Capreomycin, Amikacin, Ofloxacin, Levofloxacin, Kanamycin, Ethionamide, Para-aminosalicylic acid and Cycloserine. DST in direct PCR was performed with Allele-specific polymerase chain reaction aimed to identify rpoB, katG, inhA, embB and gyrA gene mutations associated with resistance to Isoniazid, Rifampicin, Ethambutol and fluoroquinolones [20]. All DST strictly followed the procedures and methods set out by WHO and the International Union against Tuberculosis and Lung Disease [19].

Patients with other types of drug resistance were excluded from the study. A new patient was defined as a patient with TB who had never been treated for TB previously, or who had received anti-TB drugs treatment for less than 1 month. A re-treatment patient was defined as a patient who had received anti-TB drug treatment for more than 1 month [6].

In-depth interview:

The interviewees were purposely selected based on their roles and experience in TB control. A total of 8 re-treatment and newly diagnosed patients completed the interviews, including one with a history of incarceration. In addition, 10 healthcare workers involved with their treatment likewise completed interviews, including 5 physicians and 5 health administrative officials. Patients with TB were asked to answer when, where, and why they had received TB services, as well as how they were treated and what problems did they face. The administrative officials were asked to answer questions in relation to the arrangement of treatment regimens and compliance of providers and patients. The physicians were asked to answer questions about their experiences and problems in treating patients with TB. The interviews were digitally recorded, transcribed and thematically coded. The final sample size was determined by a saturation of information when no new categories emerged.

Quantitative data analysis:

Quantitative variables of demographical, clinical characteristics of the patients with MDR/RR-TB were compared with those without MDR/RR-TB. Three regression models were constructed for all cases combined - only new cases and only re-treatment cases, respectively. Independent variables tested in the regression analysis included gender, age, social status, living conditions, substance abuse, history of imprisonment, disabilities, HIV status, history of treatment with Rifampicin and Isoniazid, TB localization, cavitary disease, place of residence, and circumstances of TB discovery. For the re-treatment patients, in addition, were included variables of previous therapy outcome and length of previous treatment with Rifampicin and Isoniazid).

Three separate binary logistic regression models were created. Chi square tests were used for testing statistical significance of the models as a whole. Fitness of the models to the data were tested with 
Hosmer \& Lemeshow test. Regression coefficient, Odds ration with $95 \%$ confidence interval $(95 \% \mathrm{Cl})$ for each variable category was calculated and Wald statistics method used to determine their statistical significance [21]. An analysis was performed using SPSS software V24.0.01.

Qualitative data analysis:

The interview data was analyzed thematically, with the coding framework developed inductively from the data. The initial coding used open coding and theoretical coding. The initial codes were then refined to produce a smaller set of themes. The coding framework was subject to continuing iterative revision during the course of analysis. An analysis was performed using Nvivo software V11.0. 
Table 1

Demographical and clinical characteristics of the recruited patients:

\begin{tabular}{|c|c|c|c|c|}
\hline Variable & $\begin{array}{l}\text { Entire sample } \\
\begin{array}{l}\mathrm{N} \text { and } \% \\
(\mathrm{n}=1440)\end{array}\end{array}$ & $\begin{array}{l}\text { New } \\
\text { cases } \\
N \text { and \% } \\
(n=1046)\end{array}$ & $\begin{array}{l}\begin{array}{l}\text { Retreatment } \\
\text { cases }\end{array} \\
\mathrm{N} \text { and \% } \\
(\mathrm{n}=394)\end{array}$ & $\begin{array}{l}\text { MDR/Non- } \\
\text { MDR-TB } \\
\text { p (Chi^2 test) }\end{array}$ \\
\hline $\begin{array}{l}\text { MDR/RR } \\
\text { MDR/RR } \\
\text { No MDR/RR }\end{array}$ & $\begin{array}{l}618(42.9) \\
822(57.1)\end{array}$ & $\begin{array}{l}363 \\
(34.7) \\
683 \\
(65.3)\end{array}$ & $\begin{array}{l}255(64.7) \\
139(35.3)\end{array}$ & - \\
\hline $\begin{array}{l}\text { Gender } \\
\text { Male } \\
\text { Female }\end{array}$ & $\begin{array}{l}1058(73.5) \\
382(26.5)\end{array}$ & $\begin{array}{l}755 \\
(72.2) \\
291 \\
(27.8)\end{array}$ & $\begin{array}{l}303(76.9) \\
91(23.1)\end{array}$ & 0.856 \\
\hline $\begin{array}{l}\text { Age, median years (range) } \\
<41 \text { years } \\
>=41 \text { years }\end{array}$ & $\begin{array}{l}715(43.7) \\
725(50.3)\end{array}$ & $\begin{array}{l}524 \\
(50.1) \\
522 \\
(49.9)\end{array}$ & $\begin{array}{l}191(48.5) \\
203(51.5)\end{array}$ & $<0.001$ \\
\hline $\begin{array}{l}\text { Place of residence } \\
\text { Countryside } \\
\text { City }\end{array}$ & $\begin{array}{l}440(30.6) \\
1000(69.4)\end{array}$ & $\begin{array}{l}311 \\
(29.7) \\
735 \\
(70.3)\end{array}$ & $\begin{array}{l}129(32.7) \\
265(67.3)\end{array}$ & 0.149 \\
\hline $\begin{array}{l}\text { Social status } \\
\text { Not working } \\
\text { Working }\end{array}$ & $\begin{array}{l}989(68.7) \\
244(16.9) \\
173(12.0)\end{array}$ & $\begin{array}{l}675 \\
(64.5) \\
203 \\
(19.4)\end{array}$ & $\begin{array}{l}314(79.7) \\
41(10.4) \\
37(9.4)\end{array}$ & - \\
\hline $\begin{array}{l}\text { Retired } \\
\text { Student } \\
\text { Not organized child } \\
\text { In military service }\end{array}$ & $\begin{array}{l}28(1.9) \\
4(0.3) \\
2(0.1)\end{array}$ & $\begin{array}{l}136 \\
(13.0) \\
26(2.5) \\
4(0.4) \\
2(0.2)\end{array}$ & $\begin{array}{l}2(0.5) \\
0 \\
0\end{array}$ & \\
\hline
\end{tabular}




\begin{tabular}{|c|c|c|c|c|}
\hline Variable & $\begin{array}{l}\text { Entire sample } \\
\begin{array}{l}\mathrm{N} \text { and } \% \\
(\mathrm{n}=1440)\end{array}\end{array}$ & $\begin{array}{l}\text { New } \\
\text { cases } \\
N \text { and \% } \\
(n=1046)\end{array}$ & $\begin{array}{l}\text { Retreatment } \\
\text { cases } \\
\mathrm{N} \text { and \% } \\
(\mathrm{n}=394)\end{array}$ & $\begin{array}{l}\text { MDR/Non- } \\
\text { MDR-TB } \\
\text { p (Chi^2 test) }\end{array}$ \\
\hline Living conditions: & $151(10.5)$ & $86(8.2)$ & $65(16.5)$ & - \\
\hline Homeless & $44(3.1)$ & $12(1.1)$ & $32(8.1)$ & \\
\hline Bed in designated facility & $13(0.9)$ & $9(0.9)$ & $4(1.0)$ & \\
\hline Room in Dormitory & $11(0.8)$ & $10(1.0)$ & $1(0.3)$ & \\
\hline $\begin{array}{l}\text { Room in separate apartment } \\
\text { Separate house } \\
\text { Separate apartment }\end{array}$ & $\begin{array}{l}335(23.3) \\
886(61.5)\end{array}$ & $\begin{array}{l}241 \\
(23.0) \\
688 \\
(65.8)\end{array}$ & $\begin{array}{l}94(23.9) \\
198(50.3)\end{array}$ & \\
\hline $\begin{array}{l}\text { Substances abuse: } \\
\text { No official records } \\
\text { Alcoholism } \\
\text { Drug abuse }\end{array}$ & $\begin{array}{l}1385(96.2) \\
51(3.5) \\
4(0.3)\end{array}$ & $\begin{array}{l}1006 \\
(97.8) \\
37(3.5) \\
3(0.3)\end{array}$ & $\begin{array}{l}379(96.2) \\
14(3.6) \\
1(0.3)\end{array}$ & - \\
\hline $\begin{array}{l}\text { Circumstance of TB discovery } \\
\text { Visit with symptoms to } \\
\text { healthcare facility } \\
\text { Discovered actively by healthcare } \\
\text { facility }\end{array}$ & $\begin{array}{l}540(37.5) \\
900(62.5)\end{array}$ & $\begin{array}{l}422 \\
(40.3) \\
624 \\
(59.7)\end{array}$ & $\begin{array}{l}118(29.9) \\
276(70.1)\end{array}$ & 0.005 \\
\hline $\begin{array}{l}\text { Imprisonment history } \\
\text { No official history of detention } \\
\text { Being in detention or history of } \\
\text { detention }\end{array}$ & $\begin{array}{l}1362(94.6) \\
78(5.4)\end{array}$ & $\begin{array}{l}1023 \\
(97.8) \\
23(2.2)\end{array}$ & $\begin{array}{l}339(86.0) \\
55(14.0)\end{array}$ & $<0.001$ \\
\hline $\begin{array}{l}\text { Cavitary disease } \\
\text { No cavities } \\
\text { Presence of cavities }\end{array}$ & $\begin{array}{l}646(44.9) \\
794(55.1)\end{array}$ & $\begin{array}{l}483 \\
(46.2) \\
563 \\
(53.8)\end{array}$ & $\begin{array}{l}163(41.4) \\
231(58.6)\end{array}$ & $<0.001$ \\
\hline $\begin{array}{l}\text { Disabilities } \\
\text { No disability } \\
\text { Presence of disability }\end{array}$ & $\begin{array}{l}1354(94.0) \\
86(6.0)\end{array}$ & $\begin{array}{l}1001 \\
(95.7) \\
45(4.3)\end{array}$ & $\begin{array}{l}353(89.6) \\
41(10.4)\end{array}$ & $<0.001$ \\
\hline
\end{tabular}




\begin{tabular}{|c|c|c|c|c|}
\hline Variable & $\begin{array}{l}\text { Entire sample } \\
\begin{array}{l}\mathrm{N} \text { and } \% \\
(\mathrm{n}=1440)\end{array}\end{array}$ & $\begin{array}{l}\text { New } \\
\text { cases } \\
N \text { and \% } \\
(n=1046)\end{array}$ & $\begin{array}{l}\begin{array}{l}\text { Retreatment } \\
\text { cases }\end{array} \\
\mathrm{N} \text { and \% } \\
(\mathrm{n}=394)\end{array}$ & $\begin{array}{l}\text { MDR/Non- } \\
\text { MDR-TB } \\
\text { p (Chi^2 test) }\end{array}$ \\
\hline TB localization: & 1401 (97.3) & \multirow{4}{*}{$\begin{array}{l}1011 \\
(96.7) \\
26(2.5) \\
9(0.9)\end{array}$} & $390(99.0)$ & \multirow[t]{4}{*}{-} \\
\hline Pulmonary TB & $29(2.0)$ & & $3(0.8)$ & \\
\hline $\begin{array}{l}\text { TB of lungs' lymph system, } \\
\text { pleural }\end{array}$ & $10(0.7)$ & & $1(0.2)$ & \\
\hline Non thoracic TB & & & & \\
\hline HIV status & 1321 (91.7) & \multirow{2}{*}{$\begin{array}{l}967 \\
(92.4) \\
79(7.6)\end{array}$} & $354(89.8)$ & \multirow[t]{2}{*}{$<0.001$} \\
\hline $\begin{array}{l}\text { Negative } \\
\text { Positive }\end{array}$ & 119 (8.3) & & $40(10.2)$ & \\
\hline
\end{tabular}

HIV - human immunodeficiency virus, TB - tuberculosis, MDR/RR - multidrug resistance/Rifampin resistance

\section{Results}

Characteristics of the study population:

During the study period, in all healthcare institutions of the Khabarovsk Krai, 2661 patients were diagnosed with TB, of which 1544 patients were found to have an active pulmonary tuberculosis and 101 patients were excluded from the study due to resistance types other then MDR/RR-TB. 3 patients were excluded due to an incomplete set of variables. In total, 1440 patients were included in this study. Participants had a median age of 41 years, and $73.5 \%$ of them were male. MDR/RR was detected in 618 $(42.9 \%, 95 \% \mathrm{Cl} 40.3-45.5 \%)$ of the study participants. $69.4 \%$ of participants resided in cities and 989 $(68.7 \%)$ of them had no official record of employment. $61.5 \%$ were living in separate apartments and 151 (10.5\%) patients were homeless in the time of TB diagnosis. There were also 2.01 times more homeless among re-treatment cases than in new TB cases (16,5\% vs $8.2 \%$ ). Alcoholism was reported in $3.5 \%$ of all cases and in $62.5 \%$ of patients, TB was discovered actively with the annual chest x-ray in primary healthcare facilities (PHF). More than half $(55.1 \%)$ of all cases showed signs of cavitary disease. Disabilities have been reported in $6 \%$ of the entire sample and $8.3 \%$ were tested positive for HIV. 78 patients $(5.4 \%)$ were in detention or had an official history of incarceration in the time of diagnosis. Incarcerated patients had a much higher prevalence of resistance in question (93.6\%, 95\% Cl 85.6$97.8 \%)$ compared to the population without a history of imprisonment $(40.0 \%, 95 \% \mathrm{Cl} 37.4-42.7 \%)$ $(p<0.001)$. 
There were 394 re-treatment patients, which comprised $27.4 \%$ of the total study sample. The re-treatment patients had greater prevalence of MDR-TB $(64.6 \%, 95 \% \mathrm{Cl} 59.8-69.4 \%)$ than the new patients $(34.8 \%$, $95 \% \mathrm{Cl} 31.8-37.7 \%)(p<0.001)($ Table 1$)$.

Factors associated with MDR/RR-TB:

With the 1440 cases entered into the multilevel model, a history of imprisonment and history of previous treatment became the strongest associative factors with MDR/RR-TB. In these cases, risk of having MDR/RR-TB was 16.53 times higher $(95 \% \mathrm{Cl} 5.37$ to $50.88, \mathrm{p}<0.001)$ and 2.82 times higher $(95 \% \mathrm{Cl} 2.16$ to $3.66, p<0.001$ ) respectively.

Other influencing factors included presence of disability (adjusted OR (AOR) is $2.32,95 \% \mathrm{Cl} 1.38$ to 3.89 , $p=0.001$ ), cavitary disease (AOR is $1.76,95 \% \mathrm{Cl} 1.37$ to $2.25, p<0.001$ ), positive HIV status (AOR $1.55,95 \%$ $\mathrm{Cl} 1.01$ to 2.39, $p=0.046$ ), age (AOR for being older than 41 years is $1.36,95 \% \mathrm{Cl} 1.06$ to $1.76, p=0.013$ ) and place of residence (AOR for residing in the city is $1.44,95 \% \mathrm{Cl} 1.09$ to $1.89, \mathrm{p}=0.01$ ) (Table 2).

The multilevel model for the newly diagnosed patients was composed of 1047 cases. Of these, 364 had MDR/RR-TB (34.7\%). History of imprisonment again became the strongest associative factor, with 11.9 times higher risk of MDR/RR-TB $(95 \% \mathrm{Cl} 2.94$ to $43.78, p<0.001)$.

Among all remaining factors, three showed association with presence of MDR/RR-TB. First, patients with underlying cavitary disease were 1.96 times more likely to have MDR/RR-TB ( $95 \% \mathrm{Cl} 1.46$ to 2.63 , $\mathrm{p}<0.001)$. Second, patients who were living in cities were 1.841 times more likely to have MDR/RR-TB ( $95 \% \mathrm{Cl} 1.25$ to $2.44, \mathrm{p}=0.001)$. Third, positive HIV status was associated with a 1.67 times increase in terms of the MDR/RR-TB risk ( $95 \% \mathrm{Cl} 1.01$ to $2.77, \mathrm{p}=0.047$ ) (Table 3).

393 cases were included in multilevel model for re-treatment patients. Here, four variables proved to be significant, with a history of incarceration remaining the strongest associative factor among all. In these cases, such patients were 38.5 times more likely to have MDR/RR-TB (95\% Cl 3.64 to 407.42, $p=0.002$ ). Elsewhere, the presence of disability led to a ratio of 4.43 times more likely to have MDR/RR-TB $(95 \% \mathrm{Cl}$ 1.47 to $13.38, p=0.008$ ). Other two significant variables were official records of employment (AOR 4.32, $95 \% \mathrm{Cl} 1.74$ to $10.71, \mathrm{p}=0.002$ ) and being discovered actively by PHF (AOR $1.79,95 \% \mathrm{Cl} 1.05$ to 3.05 , $\mathrm{p}=0.03)$ (Table 3). 
Table 2

Multivariable analysis for estimation of prevalence of MDR/RR-TB in the entire sample $(n=1440)$

\begin{tabular}{|c|c|c|c|}
\hline Variable & $\begin{array}{l}\text { Prevalence of } \\
\text { MDR/RR-TB (\%) }\end{array}$ & AOR $(95 \% \mathrm{Cl})$ & p Multilevel \\
\hline Gender & 43.1 & 1.21 (0.93 to 1.57 ) & 0.156 \\
\hline Female & 41.4 & 1 (reference) & \\
\hline \multicolumn{4}{|l|}{ Male } \\
\hline Age, median years (range) & 48 & 1.36 (1.06 to 1.76$)$ & 0.013 \\
\hline$>=41$ years & 37.9 & 1 (reference) & \\
\hline \multicolumn{4}{|l|}{$<41$ years } \\
\hline Place of residence & 44.2 & 1.43 (1.09 to 1.89$)$ & 0.010 \\
\hline City & 40.0 & 1 (reference) & \\
\hline \multicolumn{4}{|l|}{ Countryside } \\
\hline Social status (whole variable) & 39.3 & - & 0.432 \\
\hline Working & 29.3 & 1.08 (0.79 to 1.47$)$ & 0.639 \\
\hline Retired & 35.7 & 0.65 (0.43 to 0.98$)$ & 0.042 \\
\hline Student & 50 & $0.94(0.41$ to 2.15$)$ & 0.879 \\
\hline Not organized child & 100 & 0.75 (0.09 to 6.53$)$ & 0.792 \\
\hline In military service & 46.3 & - & 0.999 \\
\hline Not working & & 1 (reference) & \\
\hline Living conditions (whole variable) & 51.3 & $0.71(0.19$ to 2.65$)$ & 0.125 \\
\hline Bed in designated facility & 86.4 & 0.98 (0.29 to 3.37$)$ & 0.608 \\
\hline Room in dormitory & 46.2 & $0.14(0.02$ to 1.17$)$ & 0.978 \\
\hline Room in separate apartment & 9.1 & $1.13(0.72$ to 1.75$)$ & 0.069 \\
\hline Separate house & 43.9 & 0.80 (0.54 to 1.18$)$ & 0.595 \\
\hline Separate apartment & 39.3 & 1 (reference) & 0.258 \\
\hline Homeless & & & - \\
\hline
\end{tabular}

HIV - human immunodeficiency virus, TB - tuberculosis, MDR/RR - multidrug resistance/Rifampin resistance, AOR - adjusted odds ratio, 


\begin{tabular}{|c|c|c|c|}
\hline Variable & \multicolumn{3}{|l|}{ MDR/RR-TB (\%) } \\
\hline Substances abuse (whole variable) & 39.2 & $0.84(0.45$ to 1.56$)$ & 0.656 \\
\hline Alcoholism & 75 & 2.35 (0.23 to 24.25$)$ & 0.569 \\
\hline Drug abuse & 43 & 1 (reference) & 0.475 \\
\hline No official records & & & - \\
\hline Circumstance of TB discovery & 45.8 & $1.24(0.97$ to 1.60$)$ & 0.088 \\
\hline Discovered actively by healthcare facility & 38.1 & 1 (reference) & \\
\hline \multicolumn{4}{|l|}{ Visit with symptoms to healthcare facility } \\
\hline Imprisonment history & 93.6 & 16.53 (5.37 to 50.88$)$ & $<0.001$ \\
\hline Being in detention or history of detention & 40.0 & 1 (reference) & \\
\hline \multicolumn{4}{|l|}{ No official history of detention } \\
\hline Cavitary disease & 47.4 & 1.76 (1.37 to 2.25$)$ & $<0.001$ \\
\hline Presence of cavities & 37.5 & 1 (reference) & \\
\hline \multicolumn{4}{|l|}{ No cavities } \\
\hline Disabilities & 41.4 & 2.32 (1.38 to 3.89$)$ & 0.001 \\
\hline No disability & 67.4 & 1 (reference) & \\
\hline \multicolumn{4}{|l|}{ Presence of disability } \\
\hline TB localization: & 43.4 & $(-)$ & 0.859 \\
\hline Pulmonary TB & 0 & 1.27 (0.55 to 2.94$)-$ & 0.581 \\
\hline Non thoracic TB & 34.5 & 1 (reference) & - \\
\hline TB of lungs' lymph system, pleural & & & 0.999 \\
\hline HIV status & 53.8 & 1.55 (1.01 to 2.39$)$ & 0.046 \\
\hline Positive & 41.9 & 1 (reference) & \\
\hline \multicolumn{4}{|l|}{ Negative } \\
\hline Treatment history with I and R: & 64.6 & $2.82(2.16$ to 3.66$)$ & $<0.001$ \\
\hline Retreatment & 34.8 & 1 (reference) & \\
\hline \multicolumn{4}{|l|}{ No history } \\
\hline $\begin{array}{l}\text { HIV - human immunodeficiency virus, TB } \\
\text { resistance, AOR - adjusted odds ratio, }\end{array}$ & berculosis, MD & $\mathrm{Q}$ - multidrug resist & /Rifampin \\
\hline
\end{tabular}


Table 3

Multivariable analysis for estimation of prevalence of MDR-TB in the new cases $(n=1046)$ and retreatment cases $(n=394)$

\begin{tabular}{|c|c|c|c|c|c|c|}
\hline \multirow[t]{3}{*}{ Variable } & \multicolumn{3}{|c|}{ New cases $(n=1046)$} & \multicolumn{3}{|c|}{ Retreatment cases $(n=394)$} \\
\hline & $\begin{array}{l}\text { Prevalence } \\
\text { of }\end{array}$ & $\begin{array}{l}\text { AOR }(95 \% \\
\mathrm{Cl})\end{array}$ & $\stackrel{p}{\text { Multilevel }}$ & $\begin{array}{l}\text { Prevalence } \\
\text { of }\end{array}$ & $\begin{array}{l}\text { AOR }(95 \% \\
\mathrm{Cl})\end{array}$ & $\stackrel{p}{\text { Multilevel }}$ \\
\hline & $\begin{array}{l}\text { MDR-TB } \\
(\%)\end{array}$ & & & $\begin{array}{l}\text { MDR-TB } \\
(\%)\end{array}$ & & \\
\hline \multirow{3}{*}{$\begin{array}{l}\text { Gender } \\
\text { Female } \\
\text { Male }\end{array}$} & 36.4 & \multirow{2}{*}{$\begin{array}{l}1.25(0.92 \\
\text { to } 1.69)\end{array}$} & 0.157 & 65.6 & \multirow{2}{*}{$\begin{array}{l}1.24(0.71 \\
\text { to } 2.18)\end{array}$} & 0.441 \\
\hline & \multirow[t]{2}{*}{34.1} & & - & 61.5 & & - \\
\hline & & (reference) & & & (reference) & \\
\hline $\begin{array}{l}\text { Age, median } \\
\text { years (range) }\end{array}$ & 39.5 & $\begin{array}{l}1.34(0.99 \\
\text { to } 1.81)\end{array}$ & 0.013 & 58.1 & $\begin{array}{l}0.65(0.38 \\
\text { to } 1.09)\end{array}$ & 0.108 \\
\hline $\begin{array}{l}>=41 \text { years } \\
<41 \text { years }\end{array}$ & 30.0 & \multicolumn{2}{|l|}{$\begin{array}{l}1 \\
\text { (reference) }\end{array}$} & 71.6 & $\begin{array}{l}1 \\
\text { (reference) }\end{array}$ & - \\
\hline \multirow{3}{*}{$\begin{array}{l}\text { Place of } \\
\text { residence } \\
\text { City } \\
\text { Countryside }\end{array}$} & 37.2 & \multirow{2}{*}{$\begin{array}{l}1.841 \\
(1.32 \text { to } \\
2.57)\end{array}$} & 0.010 & 66.7 & $\begin{array}{l}1.27(0.72 \\
\text { to } 2.26)\end{array}$ & 0.408 \\
\hline & \multirow{2}{*}{28.9} & & - & 63.6 & & - \\
\hline & & $\begin{array}{l}1 \\
\text { (reference) }\end{array}$ & & & (reference) & \\
\hline \multirow{2}{*}{$\begin{array}{l}\text { Social status } \\
\text { (whole variable) }\end{array}$} & 30.5 & - & 0.604 & - & - & 0.008 \\
\hline & 24.8 & \multirow{2}{*}{$\begin{array}{l}0,83(0.58 \\
\text { to } 1.19)\end{array}$} & 0.639 & 82.9 & \multirow{2}{*}{$\begin{array}{l}4,32(0.58 \\
\text { to } 1.19)\end{array}$} & 0.002 \\
\hline Working & 30.8 & & 0.042 & 45.9 & & 0.042 \\
\hline Retired & 50.0 & $\begin{array}{l}0.66(0.41 \\
\text { to } 1.07)\end{array}$ & 0.879 & 100.0 & $\begin{array}{l}0.66(0.29 \\
\text { to } 1.49)\end{array}$ & 0.999 \\
\hline \multirow{2}{*}{$\begin{array}{l}\text { Not organized } \\
\text { child }\end{array}$} & 100.0 & \multirow{2}{*}{$\begin{array}{l}0.75(0.31 \\
\text { to } 1.86)\end{array}$} & 0.792 & 0.0 & - & 0.999 \\
\hline & 37.9 & & 0.999 & 0.0 & - & 0.999 \\
\hline In military service & & to 6.81 ) & - & 64.2 & - & - \\
\hline Not working & & $\begin{array}{l}- \\
1 \\
\text { (reference) }\end{array}$ & & & $\begin{array}{l}1 \\
\text { (reference) }\end{array}$ & \\
\hline
\end{tabular}

HIV - human immunodeficiency virus, TB - tuberculosis, MDR/RR - multidrug resistance/Rifampin resistance, AOR - adjusted odds ratio 


\begin{tabular}{|c|c|c|c|c|c|c|}
\hline \multirow[t]{3}{*}{ Variable } & \multicolumn{3}{|c|}{ New cases $(n=1046)$} & \multicolumn{3}{|c|}{ Retreatment cases ( $n=394)$} \\
\hline & $\begin{array}{l}\text { Prevalence } \\
\text { of }\end{array}$ & $\begin{array}{l}\mathrm{AOR}(95 \% \\
\mathrm{Cl})\end{array}$ & Multilevel & $\begin{array}{l}\text { Prevalence } \\
\text { of }\end{array}$ & $\begin{array}{l}\mathrm{AOR}(95 \% \\
\mathrm{Cl})\end{array}$ & Multilevel \\
\hline & \multicolumn{3}{|l|}{$\begin{array}{l}\text { MDR-TB } \\
(\%)\end{array}$} & \multicolumn{3}{|l|}{$\begin{array}{l}\text { MDR-TB } \\
(\%)\end{array}$} \\
\hline \multirow{2}{*}{$\begin{array}{l}\text { Living conditions } \\
\text { (whole variable) }\end{array}$} & 66.7 & \multirow{2}{*}{$\begin{array}{l}0.73(0.12 \\
\text { to } 4.37)\end{array}$} & 0.534 & 93.8 & \multirow{2}{*}{$\begin{array}{l}0.43(0.05 \\
\text { to } 3.68)\end{array}$} & 0.526 \\
\hline & 22.2 & & 0.608 & 100.0 & & 0.439 \\
\hline $\begin{array}{l}\text { facility } \\
\text { farignated }\end{array}$ & 0.0 & $\begin{array}{l}0.64(0.12 \\
\text { to } 3.43)\end{array}$ & 0.978 & 100.0 & - & 0.999 \\
\hline \multirow{2}{*}{$\begin{array}{l}\text { Room in } \\
\text { dormitory }\end{array}$} & 37.3 & - & 0.999 & 60.6 & \multirow{2}{*}{$\begin{array}{l}0.78(0.35 \\
\text { to } 1.77)\end{array}$} & 0.999 \\
\hline & 33.7 & \multirow{2}{*}{$\begin{array}{l}1.379 \\
(0.79 \text { to } \\
2.40)\end{array}$} & 0.595 & 59.1 & & 0.560 \\
\hline apartment & \multirow[t]{4}{*}{37.2} & & 0.28 & 70.3 & \multirow{4}{*}{$\begin{array}{l}0.52(0.26 \\
\text { to } 1.05) \\
1 \\
\text { (reference) }\end{array}$} & 0.070 \\
\hline Separate house & & $\begin{array}{l}0.98(0.60 \\
\text { to } 1.61)\end{array}$ & - & & & - \\
\hline $\begin{array}{l}\text { Separate } \\
\text { apartment }\end{array}$ & & \multirow{2}{*}{\multicolumn{2}{|c|}{1 (reference) }} & & & \\
\hline Homeless & & & & & & \\
\hline \multirow{2}{*}{$\begin{array}{l}\text { Substances } \\
\text { abuse (whole } \\
\text { variable) }\end{array}$} & 32.4 & - & 0.991 & 57.1 & - & 0.539 \\
\hline & 66.7 & \multirow[t]{2}{*}{$\begin{array}{l}0.97(0.47 \\
\text { to } 1.99)\end{array}$} & 0.935 & 100.0 & \multirow[t]{2}{*}{$\begin{array}{l}0.48(0.13 \\
\text { to } 1.73)\end{array}$} & 0.266 \\
\hline Alcoholism & \multirow[t]{3}{*}{34.8} & & 0.914 & 64.8 & & 0.999 \\
\hline Drug abuse & & $\begin{array}{l}1.15(0.09 \\
\text { to } 14.14)\end{array}$ & - & & \multirow{2}{*}{1 (reference) } & - \\
\hline No official records & & $\begin{array}{l}1 \\
\text { (reference) }\end{array}$ & & & & \\
\hline $\begin{array}{l}\text { Circumstance of } \\
\text { TB discovery }\end{array}$ & 35.3 & $\begin{array}{l}1.18(0.88 \\
\text { to } 1.57)\end{array}$ & \multirow[t]{2}{*}{0.278} & 69.6 & $\begin{array}{l}1.79(1.06 \\
\text { to } 3.05)\end{array}$ & \multirow[t]{2}{*}{0.030} \\
\hline $\begin{array}{l}\text { Discovered } \\
\text { actively by } \\
\text { healthcare facility }\end{array}$ & 34.0 & $\begin{array}{l}1 \\
\text { (reference) }\end{array}$ & & 53.0 & $\begin{array}{l}1 \\
\text { (reference) }\end{array}$ & \\
\hline $\begin{array}{l}\text { Visit with } \\
\text { symptoms to } \\
\text { healthcare facility }\end{array}$ & & & & & & \\
\hline
\end{tabular}

HIV - human immunodeficiency virus, TB - tuberculosis, MDR/RR - multidrug resistance/Rifampin resistance, AOR - adjusted odds ratio 


\begin{tabular}{|c|c|c|c|c|c|c|}
\hline \multirow[t]{3}{*}{ Variable } & \multicolumn{3}{|c|}{ New cases $(n=1046)$} & \multicolumn{3}{|c|}{ Retreatment cases $(n=394)$} \\
\hline & $\begin{array}{l}\text { Prevalence } \\
\text { of }\end{array}$ & $\begin{array}{l}\mathrm{AOR}(95 \% \\
\mathrm{Cl})\end{array}$ & $\stackrel{p}{\text { Multilevel }}$ & $\begin{array}{l}\text { Prevalence } \\
\text { of }\end{array}$ & $\begin{array}{l}\mathrm{AOR}(95 \% \\
\mathrm{Cl})\end{array}$ & Multilevel \\
\hline & $\begin{array}{l}\text { MDR-TB } \\
(\%)\end{array}$ & & & $\begin{array}{l}\text { MDR-TB } \\
(\%)\end{array}$ & & \\
\hline \multirow{2}{*}{$\begin{array}{l}\text { Imprisonment } \\
\text { history } \\
\text { Being in detention } \\
\text { or history of } \\
\text { detention }\end{array}$} & & \multirow{2}{*}{$\begin{array}{l}11.9(3.08 \\
\text { to } 45.93) \\
1 \\
\text { (reference) }\end{array}$} & \multirow[t]{2}{*}{$<0.001$} & & \multirow{2}{*}{$\begin{array}{l}38.55 \\
(3.65 \text { to } \\
407.42) \\
\\
1 \\
\text { (reference) }\end{array}$} & \multirow[t]{2}{*}{0.002} \\
\hline & 33.7 & & & 59.2 & & \\
\hline \multicolumn{7}{|l|}{$\begin{array}{l}\text { No official history } \\
\text { of detention }\end{array}$} \\
\hline Cavitary disease & 40.1 & \multirow{2}{*}{$\begin{array}{l}1.95(1.45 \\
\text { to } 2.62) \\
1 \\
\text { (reference) }\end{array}$} & \multirow[t]{2}{*}{$<0.001$} & 65.2 & \multirow{2}{*}{$\begin{array}{l}1.46(0.87 \\
\text { to } 2.44) \\
1 \\
\text { (reference) }\end{array}$} & \multirow[t]{2}{*}{0.151} \\
\hline $\begin{array}{l}\text { Presence of } \\
\text { cavities } \\
\text { No cavities }\end{array}$ & 28.6 & & & 63.8 & & \\
\hline Disabilities & 48.9 & \multirow{2}{*}{$\begin{array}{l}1.66(0.87 \\
\text { to } 3.15) \\
1 \\
\text { (reference) }\end{array}$} & \multirow[t]{2}{*}{0.119} & 87.8 & \multirow{2}{*}{$\begin{array}{l}4.44(1.47 \\
\text { to } 13.38) \\
1 \\
\text { (reference) }\end{array}$} & \multirow[t]{2}{*}{0.008} \\
\hline $\begin{array}{l}\text { Presence of } \\
\text { disability } \\
\text { No disability }\end{array}$ & 34.1 & & & 61.9 & & \\
\hline TB localization: & 38.5 & $(-)$ & 0.494 & 0.0 & - & 0.999 \\
\hline \multirow{2}{*}{$\begin{array}{l}\text { TB of lungs' } \\
\text { lymph system, } \\
\text { pleural }\end{array}$} & 0.0 & $\begin{array}{l}1.69(0.71 \\
\text { to } 4.04)-\end{array}$ & 0.235 & 0.0 & \multirow{3}{*}{$\begin{array}{l}1 \\
\text { (reference) }\end{array}$} & 0.999 \\
\hline & \multirow[t]{2}{*}{35.0} & \multirow[t]{2}{*}{$\begin{array}{l}1 \\
\text { (reference) }\end{array}$} & $\begin{array}{l}0.999 \\
-\end{array}$ & 65.3 & & $\begin{array}{l}0.999 \\
-\end{array}$ \\
\hline \multicolumn{3}{|l|}{ Pulmonary TB } & & & & - \\
\hline HIV status & 46.8 & \multirow{2}{*}{$\begin{array}{l}1.67(1.01 \\
\text { to } 2.77) \\
1 \\
\text { (reference) }\end{array}$} & \multirow[t]{2}{*}{0.047} & 67.5 & \multirow{2}{*}{$\begin{array}{l}1.48(0.62 \\
\text { to } 3.53) \\
1 \\
\text { (reference) }\end{array}$} & \multirow{2}{*}{$\begin{array}{l}0.378 \\
-\end{array}$} \\
\hline $\begin{array}{l}\text { Positive } \\
\text { Negative }\end{array}$ & 33.8 & & & 64.3 & & \\
\hline Previous therapy & \multirow[t]{2}{*}{-} & \multirow[t]{2}{*}{-} & \multirow[t]{2}{*}{-} & 61.4 & \multirow{2}{*}{$\begin{array}{l}0.92(0.56 \\
\text { to } 1.51) \\
1 \\
\text { (reference) }\end{array}$} & \multirow[t]{2}{*}{0.732} \\
\hline $\begin{array}{l}\text { More than } 180 \\
\text { days } \\
\text { Less than } 180 \\
\text { days }\end{array}$ & & & & 69.7 & & \\
\hline
\end{tabular}

HIV - human immunodeficiency virus, TB - tuberculosis, MDR/RR - multidrug resistance/Rifampin resistance, AOR - adjusted odds ratio 


\begin{tabular}{|c|c|c|c|c|c|c|}
\hline \multirow[t]{3}{*}{ Variable } & \multicolumn{3}{|c|}{ New cases $(n=1046)$} & \multicolumn{3}{|c|}{ Retreatment cases ( $n=394)$} \\
\hline & $\begin{array}{l}\text { Prevalence } \\
\text { of }\end{array}$ & $\begin{array}{l}\text { AOR }(95 \% \\
\mathrm{Cl})\end{array}$ & Multilevel & $\begin{array}{l}\text { Prevalence } \\
\text { of }\end{array}$ & $\begin{array}{l}\mathrm{AOR}(95 \% \\
\mathrm{Cl})\end{array}$ & Multilevel \\
\hline & \multicolumn{3}{|l|}{$\begin{array}{l}\text { MDR-TB } \\
\text { (\%) }\end{array}$} & \multicolumn{3}{|l|}{$\begin{array}{l}\text { MDR-TB } \\
(\%)\end{array}$} \\
\hline \multirow{2}{*}{$\begin{array}{l}\text { Previous therapy } \\
\text { outcome }\end{array}$} & \multirow[t]{7}{*}{-} & \multirow[t]{7}{*}{-} & \multirow[t]{7}{*}{-} & 79.3 & - & 0.061 \\
\hline & & & & 0.0 & \multirow{2}{*}{$\begin{array}{l}1.379 \\
(0.79 \text { to } \\
2.40)\end{array}$} & 0.621 \\
\hline $\begin{array}{l}\text { Not entective } \\
\text { course }\end{array}$ & & & & 100.0 & & 0.999 \\
\hline Other & & & & 52.5 & - & 0.999 \\
\hline Transferred & & & & 61.4 & - & 0.089 \\
\hline Interrupted course & & & & & \multirow{2}{*}{$\begin{array}{l}0.98(0.60 \\
\text { to } 1.6111 \\
\text { (reference) }\end{array}$} & \multirow[t]{2}{*}{-} \\
\hline Effective course & & & & & & \\
\hline
\end{tabular}

\section{Interpretation of Interviews:}

Findings of quantitative data analysis were partially supported by interviews with patients, health managers, and physicians.

All aspects of TB care in Russia are free of charge. The whole system was designed to provide universal, quality and specialized care that is centralized in TB-designated facilities (TBDF), as depicted on the Figure 1. The one exception from the system is penitentiary facilities that operate separately. As was reported by interviewees, poor nutrition and living conditions, overcrowding, treatment regimens neglect by prisons' medical stuff and prisoners, make these institutions the breeding ground for drug resistance. After releasing from detention, prisoners mostly disappear from epidemiological surveillance and, even if they show up for further treatment, they often fail to adhere to the regimen and follow-up procedures and there is no legal tools for healthcare providers to enforce surveillance on them.

There was a consensus among interviewees, that the main obstacle toward achieving full patient's compliance, is the length of therapy. Patients become progressively tired as the treatment advances, especially those ones with drug resistance, whose regimens usually last for 24 months or even more. That, combined with insufficient awareness about consequences of intermitted treatment, leads patients to drop out from the treatment, usually as soon as symptoms disappear.

Healthcare providers stated that both outcome and history of previous treatment contribute to the resistance development contrary to our results that mere fact of previous treatment history is increasing risk of resistance presence regardless of its outcome. Same goes for social status and living conditions, which, according to our statistical data, do not influence resistance development, but from a clinical 
standpoint, socially disadvantaged patients (particularly homeless ones) display a greater tendency to acquire MDR/RR TB. Other substantial problem, that was not supported by data but reported by interviewees, is a greater frequency of alcohol and substances abuse. MDR/RR -TB prevalence in those groups is significantly higher than average.

Significance of disability as a risk factor was a surprise for interviewees; physicians stated that some patients purposely do not comply with treatment in order to worsen their condition and acquire disability status for receiving social security benefits.

City dwellers have better access to healthcare in general and have a far greater capacity to complete annual chest $X$-rays in particular. Therefore, cities tend to see a far greater number of people diagnosed with TB than in rural areas. Likewise, the increased population density in cities provides more chances to contract MDR / RR - TB. This can explain an emerging trend observed by physicians - namely, the increase in the prevalence of MDR / RR-TB among newly diagnosed patients.

\section{Discussion}

Besides the TB mycobacterium's major biological features leading to the prevalence of MDR/RR-TB, such as mutation potential [22], strains [23] and draft genome sequences [24], TB related service patterns, demographics and clinical factors also have a significant impact on the development of MDR/RR-TB.

Not surprisingly, incarceration history was identified as the strongest risk factor associated with MDR/RRTB in all studied groups. In this data, a high prevalence of TB and its drug resistant forms can be seen in prisons all around the world, developed and developing countries alike [25-27].

Given this, we propose that Russian penitentiary system makes a significant contribution toward increasing prevalence of drug resistant tuberculosis. In 2021, according to Birkbeck University of London, Russia occupies 5th place in the world in term of total prison population. This creates a substantial pool of hosts, carrying drug resistant TB in the population [28]. Among all healthcare facilities in Russia, only penitentiary facilities isolated from the general TB care system (Fig. 1). Such demarcation deprives inmates of proper care and follow up. Either a considerable reduction in the total prison population or inclusion of penitentiary facilities in the TB care system may address the problem.

In addition, this ongoing predicament is explained by a contradiction of Russian laws in the field of healthcare. No medical procedures can be instituted without a patient's consent, including hospitalization, so some patients just leave TBDF at will. In order to ensure epidemiological surveillance, healthcare providers have to file a claim for forced hospitalization to the court. Paradoxically, there is no legal mechanisms to execute positive court decision without patient written consent, even infectious TB patients can leave TBDF even with court decision of forced hospitalization. In 2011 it was that 3500 out of 6000 lawsuits were satisfied in favor of forced hospitalization, and it took an average of 3 months to obtain court decision and up to $30 \%$ of patients left TBDF after forced hospitalization [29]. In order to 
ensure proper TB surveillance, drastic measures should be taken to eliminate such a loophole in the legal framework.

For reducing the pool of former inmates with MDR/RR-TB, better treatment conditions and epidemiological surveillance in penitentiary facilities must be established. Such intervention of providing TB care for inmates in civil clinics has been implemented in the Tomsk oblast region of Russia from 2000 to 2002. The results showed significant increase in compliance, reduction in adverse effect, decrease of TB mortality rate, and increased treatment efficiency among incarcerated patients. Success of this study supports necessity of centralized TB care for all TB patients, but thus far, attempts were made in that direction have proven insufficient [30].

2009 study from Belarus similarly identified positive association between disability and MDR/RR-TB prevalence [31]. In Russia, just like in Belarus, disability is a social security policy for people with permanent inability to work. Such studies may support disability status as a risk factor or revile its connection to social security policies. Therefore, there is a need for further investigation of that phenomenon in countries with and without such policies. It should be mentioned as limitation, that we had no data on whether disability was TB-related or determined by another disease, thus the full statistical meaning of this variable remains uncertain.

Our results concerning association between MDR/RR-TB with younger age, cavitary disease, and positive HIV status correspond with previous studies [27, 32, 33].

Our study has several limitations. We failed to explain the significance of official employment status as a risk factor among re-treatment patients and insignificance of social status and living conditions, as these results contradict with previous studies [11,34-36]. Also, our data indicates that outcome of previous treatment does not influence risk of MDR/RR-TB development which contradicts with previous studies and healthcare providers' interviews [32].

In the end, we want to say that further attempts to better patients' education and public awareness about TB, with continuing coordinated and centralized care for patients with TB, in tandem with greater compliance by patients with TB treatment guidelines, are the keys to success in the battle against MDR/RR-TB.

\section{Declarations}

\section{Ethics approval and consent to participate:}

The informed consents were accepted and signed by all participants and legal guardians of the underage participants of the study. All methods used in the study were performed in accordance with the relevant guidelines and regulations. The Ethics Committees of Harbin Medical University and Far Eastern State Medical University approved the study.

\section{Consent for publication}


Not applicable, as no identifiable information of the participants was revealed in the manuscript.

\section{Availability of data and materials}

The datasets analyzed during the current study are under jurisdiction of corresponding authority body and are not publicly available, but are available from the corresponding author on reasonable request due to need of corresponding authority body notification of data sharing with the third party.

\section{Competing interests}

None declared.

\section{Funding}

We received no funding from the third parties.

\section{Authors' contributions}

IB, QW, PR designed and planned this study; IB undertook data collection, performed statistical analysis, conducted interviews and wrote the draft; OD provided access to the data, follow up the study on data collection and interviews conduction as well as guidance and expert opinion on TB matters; QW, PR, OD revised, proofread and edited the paper.

\section{Acknowledgements}

The authors thank the staff of central "Tuberculosis Hospital" of Khabarovsk Krai for their support, access to the data and help with this study as well as Kremer M. for the proofreading and editing of the paper.

\section{Authors' information}

${ }^{1}$ Harbin Medical University, School of Public Health, Social medicine department, China, Harbin,

${ }^{2}$ Far Eastern State Medical University, Public health and health care department, Russia, Khabarovsk.

${ }^{3}$ Far Eastern State Medical University, Internal diseases department with the course of phthisiology, Russia, Khabarovsk.

\section{References}

1. Caminero Luna JA, Pérez Mendoza G, Rodríguez de Castro F. Multi-drug resistant tuberculosis, ten years later. Med Clin (Barc). 2021. Apr. 23;156(8):393-401. 10.1016/j.medcli.2020.08.018.

2. Park M, Padayachee $Y$, Ryan $L$, et al P157†Multidrug resistant tuberculosis - patients' perspective and experiences in a London TB centre. 2 Thorax. 2021. Jan; 76: A174. 10.1136/thorax-2020- 


\section{BTSabstracts.302}

3. Pedrazzoli, D. The Economic Burden of Tuberculosis and the Mitigation Effect of Social Protection: A Population-Based Study in Ghana. PhD thesis, London School of Hygiene \& Tropical Medicine. 2020. 10.17037/PUBS.04658405

4. Global tuberculosis report 2020: executive summary. Geneva: World Health Organization; 2020. Available from: https://apps.who.int/iris/bitstream/handle/10665/337538/9789240016941ara.pdf?isAllowed=y\&sequence $=5$ [cited 2021 Sep 15]

5. Shilova M.V. Tuberculosis in population of Russian Federation. Medical alphabet. 2019. Nov;1(15):718. 10.33667/2078-5631-2019-1-15(390)-7-18

6. WHO consolidated guidelines on tuberculosis: module 4: treatment: drug-resistant tuberculosis treatment. Geneva: World Health Organization; 2020. Available from: https://apps.who.int/iris/bitstream/handle/10665/332397/9789240007048-eng.pdf [cited 2021 Sep 15]

7. Chang L, Su Y, Zhu R, Duan Z. Mapping international collaboration in tuberculosis research from 1998 to 2017: A scientometric study. Medicine (Baltimore). 2019. Sep; 98(37):e17027. 10.1097/MD.0000000000017027

8. Migliori GB, Tiberi S, Zumla A, Petersen E, Chakaya JM, Wejse C, et al. members of the Global Tuberculosis Network. MDR/XDR-TB management of patients and contacts: Challenges facing the new decade. The 2020 clinical update by the Global Tuberculosis Network. Int J Infect Dis. 2020 Mar; 92S:S15-S25. 10.1016/j.jijid.2020.01.042.

9. Tenzin C, Chansatitporn N, Dendup T, Dorji T, Lhazeen K, Tshering D, Pelzang T. Factors associated with multidrug-resistant tuberculosis (MDR-TB) in Bhutan: A nationwide case-control study. PLoS One. 2020. Jul 27;15(7): e0236250.10.1371/journal.pone.0236250.

10. Demile B, Zenebu A, Shewaye H, Xia S, Guadie A. Risk factors associated with multidrug-resistant tuberculosis (MDR-TB) in a tertiary armed force referral and teaching hospital, Ethiopia. BMC Infect Dis. 2018 May 31;18(1):249. 10.1186/s12879-018-3167-9.

11. Rumende, Cleopas Martin. "Risk factors for multidrug-resistant tuberculosis." Acta Medica Indonesiana. 2018. Apr 1.50(1) 10.22159/ijap.2019.v11s6.33539

12. Pradipta, Ivan Surya, et al. Risk factors of multidrug-resistant tuberculosis: A global systematic review and meta-analysis. Journal of Infection. 2018. Dec 77.6: 469-478. 10.1016/j.jinf.2018.10.004

13. Lu, Z., Jiang, W., Zhang, J., Lynn, H. S., Chen, Y., Zhang, S et al. Drug resistance and epidemiology characteristics of multidrug-resistant tuberculosis patients in 17 provinces of China. Plos one. 2019. Nov 14.11: e0225361. 10.1371/journal.pone.0225361

14. Astafyev V.A., Ogarkov O.B., Zhdanov S.N., Kravchenko A.F., Vinokurova M.K., Chemezova N.N., Zorkaltseva E.Yu., Shugayeva S.N., Savilov E.D. Tuberculosis features in federal districts of the Russian Federation. Acta Biomedica Scientifica. 2017. Nov; 2(5(1)):168-173.

10.12737/article_59e859b2681e23.53680380 
15. Kimerling ME, Slavuckij A, Chavers S, Peremtin GG, Tonkel T, Sirotkina O, Golubchikova V, Baddeley A. The risk of MDR-TB and polyresistant tuberculosis among the civilian population of Tomsk city, Siberia, 1999. Int J Tuberc Lung Dis. 2003 Sep;7(9):866-72.

16. Gelberg I.S., Wolf S.B., Alekso E.N. et al. Risk factors of multidrug-resistant tuberculosis development. Kursk Scientific and Practical Bulletin. 2015. Jan;1:17-22. Russian.

17. Zhao, Y., Zagdyn, Z., Pavlova, M., Archakova, L., Sokolovich, E., \& Yablonskiy, P. et al. TB and HIV in the Russian Federation: Risk Factors of MDR-TB in HIV-infected Patients. Medical alliance. 2020. Jan. 8(1), 6-13. 10.36422/23076348-2020-8-1-6-13

18. Testov V.V., Sterlikov S.A., Vasilyeva I.A., Sidorova I.A., Mikhaylova Yu.V. et al. Federal Register of TB Cases as a tool for monitoring the impact of COVID-19 pandemic response activities on the TB care system. Tuberculosis and Lung Diseases. 2020. Nov. 98(11):6-11. 10.21292/2075-1230-2020-98-116-11

19. Guidelines for surveillance of drug resistance in tuberculosis 5th editiom. Geneva: World Health Organization; 2020. Available from:

http://apps.who.int/iris/bitstream/handle/10665/174897/9789241549134_eng.pdf?sequence=1 [cited 2021 Sep 15]

20. Ohno H, Koga $\mathrm{H}$, Kohno S. Multidrug-resistant tuberculosis. 2. Mechanisms of drug-resistance in Mycobacterium tuberculosis--genetic mechanisms of drug-resistance. Kekkaku: Tuberculosis. 1998. Nov;73(11):657-663. Japanese.

21. Harrell, F. E. Binary logistic regression: In Regression modeling strategies. Springer, Cham. 2015. 219-274. 10.1007/978-3-319-19425-7_10

22. Walker, T. M., Kohl, T. A., Omar, S. V., Hedge, J., Elias, C. D. O., Bradley, P. et al. Whole-genome sequencing for prediction of Mycobacterium tuberculosis drug susceptibility and resistance: a retrospective cohort study. The Lancet infectious diseases. 2015. Oct. (10), 1193-1202. 10.1016/S1473-3099(15)00062-6

23. Pang, Y., Zhou, Y., Zhao, B., Liu, G., Jiang, G., Xia, H., Zhao, Y. L. et al. Spoligotyping and drug resistance analysis of Mycobacterium tuberculosis strains from national survey in China. PloS one. 2012. Mar. 7(3). 10.1371/journal.pone.0032976

24. Zainal Abidin N, Noorizhab MNF, Teh LK, Lim WF, Mohd Noordin N, Aziz ZA, Abu Bakar Z, Ismail Al, Mohd Nor N, Salleh MZ. Draft Genome Sequences of Local Clinical Isolates of Drug-Resistant and Drug-Sensitive Mycobacterium tuberculosis. Microbiol Resour Announc. 2021. Jun. 10(25). 10.1128/MRA.00352-21

25. Roycroft, E., Fitzgibbon, M. M., Kelly, D. M., Scully, M., McLaughlin, A. M., Flanagan, P. R., Keane, J. et al. The largest prison outbreak of TB in Western Europe investigated using whole-genome sequencing. The International Journal of Tuberculosis and Lung Disease. 2021. Jun. 25(6). 491497. 10.5588/ijtld.21.0033

26. Gatechompol, S., Harnpariphan, W., Supanan, R., Suwanpimolkul, G., Sophonphan, J., Ubolyam, S., ... Kawkitinarong, K. Prevalence of latent tuberculosis infection and feasibility of TB preventive therapy 
among Thai prisoners: a cross-sectional study. BMC Public Health. 2021. Jun. 21(1). 1-8.

10.1186/s12889-021-11271-0

27. Dolan K, Wirtz AL, Moazen B. et al. Global burden of HIV, viral hepatitis, and tuberculosis in prisoners and detainees. Lancet. 2016. Sep. 388:1089-1102. 10.1016/S0140-6736(16)30466-4.

28. Highest to Lowest - Prison Population Total. Birkbeck University of London; 2021. Available from: https://www.prisonstudies.org/highest-to-lowest/prison-population-total [cited 2021 Sep 15]

29. Bogorodskaya E.M., Smerdin S.V., Sterlikov S.A. Organizational aspects of treatment of patients with tuberculosis in modern socio-economic conditions. Moscow. 2011. 50-75. Russian.

30. Shin, S. S., Pasechnikov, A. D., Gelmanova, I. Y., Peremitin, G. G., Strelis, A. K., Andreev, Y. G., ... Keshavjee, S. Treatment outcomes in an integrated civilian and prison MDR-TB treatment program in Russia. The International Journal of Tuberculosis and Lung Disease. 2006. Oct. 10(4), 402-408.

31. Skrahina A, Hurevich H, Zalutskaya A, Sahalchyk E, Astrauko A, Hoffner S, Rusovich V, Dadu A, de Colombani P, Dara M, van Gemert W, Zignol M. Multidrug-resistant tuberculosis in Belarus: the size of the problem and associated risk factors. Bull World Health Organ. 2013. Jan. 91(1):36-45. 10.2471/BLT.12.104588

32. Liang L, Wu Q, Gao L, Hao Y, Liu C, Xie Y, Sun H, Yan X, Li F, Li H, Fang H, Ning N, Cui Y, Han L. Factors contributing to the high prevalence of multidrug-resistant tuberculosis: a study from China. Thorax. 2012. Jul. 67(7):632-8. 10.1136/thoraxjnl-2011-200018

33. Saifullah A, Mallhi TH, Khan YH, Iqbal MS, Alotaibi NH, Alzarea Al, Rasheed M. Evaluation of risk factors associated with the development of MDR- and XDR-TB in a tertiary care hospital: a retrospective cohort study. PeerJ. 2021. Mar. 18; 9. 10.7717/peerj.10826.

34. Story A, Murad S, Roberts W, Verheyen M, Hayward AC; London Tuberculosis Nurses Network. Tuberculosis in London: the importance of homelessness, problem drug use and prison. Thorax. 2007. Aug. 62(8):667-71.10.1136/thx.2006.065409.

35. Woldesemayat EM. Tuberculosis in Migrants is Among the Challenges of Tuberculosis Control in High-Income Countries. Risk Manag Healthc Policy. 2021. Jul. 12; 14: 2965-2970. 10.2147/RMHP.S314777.

36. Alemu A, Bitew ZW, Worku T, Gamtesa DF, Alebel A. Predictors of mortality in patients with drugresistant tuberculosis: A systematic review and meta-analysis. PLoS One. 2021. Jun. 16(6). 10.1371/journal.pone.0253848.

\section{Figures}




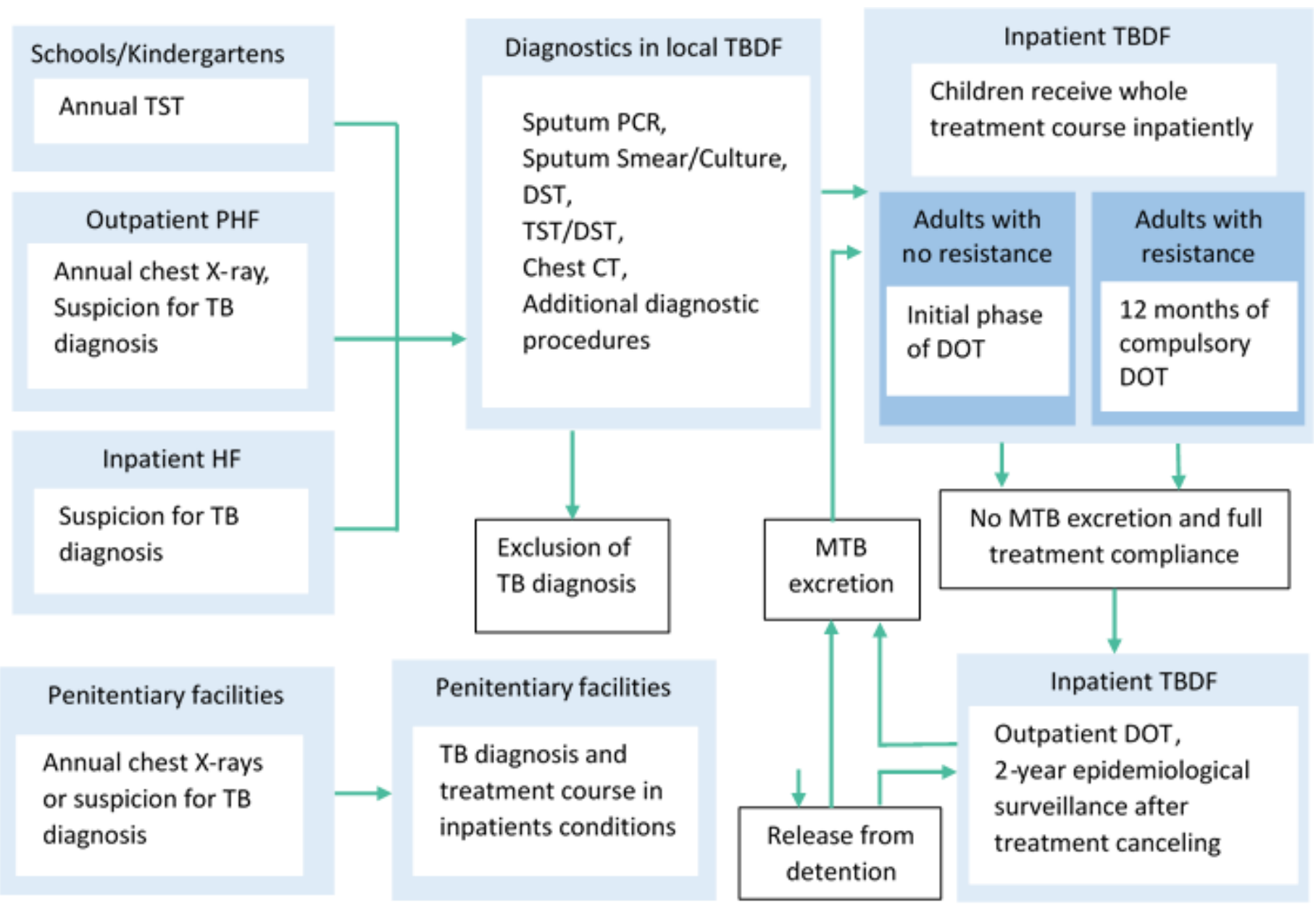

\section{Figure 1}

\section{Organization of TB care in Russia}

PHF - primary healthcare facility; HF - healthcare facility; TBDF - TB designated facility; DOT - directly observed treatment; PCR - polymerase chain reaction; TST - tuberculin skin test; DST - drug susceptibility testing; DST- Diaskin skin test; CT - computed tomography; MTB - mycobacterium tuberculosis. 